\title{
A Bus Rapid Transit Line Case Study: Istanbul's Metrobüs System
}

\author{
M. Anıl Yazıcı \\ Region-2 University Transportation Research Center, New York \\ Herbert S. Levinson, P.E., NAE \\ Mustafa llıcalı \\ Bahçeşehir University, Istanbul \\ Nilgün Camkesen \\ Bahçeşehir University, Istanbul \\ Camille Kamga \\ City College of New York
}

\begin{abstract}
Implementation of Metrobüs, the first bus rapid transit (BRT) line in Istanbul, Turkey, started in 2007. Since then, the line has been extended several times. After opening of the fourth phase in 2012, the BRT line will extend for $51.3 \mathrm{~km}$. Currently, Metrobüs carries around 600,000 passengers per day. It is the only intercontinental BRT system in the world. This paper describes Istanbul's Metrobüs system features and usage and its reported benefits and costs. It also gives the reasons that underlie the positive public reception and the rapid ridership increase.
\end{abstract}




\section{Introduction}

High levels of traffic congestion in urban areas and constrained resources require public agencies to fund timely and effective solutions, preferably with low initial costs. Istanbul's intercontinental Metrobüs bus rapid transit (BRT) line is one such solution. The line, first opened in 2007 and progressively expanded, carries a large number of riders and has dramatically reduced travel times.

This paper describes the Metrobüs system and identifies the reasons underlying the rapid increase in ridership and public acceptance. It overviews Istanbul's various public transportation systems, gives the history and physical features of the Metrobüs project, and sets forth ridership trends, rider demographics, and changes in accessibility and modal shift. The presented analysis is largely based on the data provided by the Istanbul Public Transport Authority (IETT), the Metrobüs operator. It also presents the reported benefits of Metrobüs and the passenger attitudes based on a survey conducted by IETT. The paper then compares Metrobüs features and performance with major BRT lines elsewhere in the world. It concludes with a discussion of the role of Metrobüs in Istanbul's public transportation system and the reasons underlying its popularity.

\section{Transportation in Istanbul}

Istanbul is one of the largest cities in the world, with a population of more than 13 million inhabitants, according to the 2010 census (TurkStat 2010). Similar to New York City and other megacities similar in size and complexity, Istanbul's metropolitan area is even larger. The Bosporus Sea channel divides the city into two parts and connects the Black Sea and Mediterranean Sea through the Marmara Sea. It also forms the natural boundary between Europe and Asia. Despite the Bosporus's positive impact on the city's landscape and historic development, it concentrates and complicates access within the city. The two sides of Istanbul are connected by two highway bridges (the Bosporus Bridge and the Fatih Sultan Mehmet Bridge) and by maritime transportation (ferries, passenger boats). The demand for maritime transportation is limited since it serves only certain waterfront locations.

The Bosporus Bridge (also known as the First Bridge) was completed in 1973 and became increasingly congested in subsequent years. The Fatih Sultan Mehmet Bridge (the Second Bridge) project started in 1986 and was completed in 1988. The two bridges accommodate only highway vehicles-cars, trucks, and buses. The Marmaray project, an underground rail tunnel, is under construction and, when completed, will also connect the European and Asian sides of Istanbul. At pres- 
ent, passenger transportation between the residentially-heavy Asian side and the business-oriented European side can use only using the two existing bridges over the Bosporus, which are congested for many hours each day.

Car ownership in Istanbul is lower than in other European cities. It has increased substantially over the last decade, significantly exceeding population growth (Gercek and Demir 2008). The current car ownership rate is 134 cars per 1,000 inhabitants; about 65 percent of households in Istanbul do not have a car (Gercek and Demir 2008).

Transportation in Istanbul mainly relies on road-based transportation (92.3\%), followed by rail (5.5\%) and water (2.2\%) (Gunay 2007). The city's residents have a strong dependence on the its comprehensive public transportation system. Overall, 53 percent of the population use one or more forms of public transportation (Gunay 2007), including commuter rail, metro, light rail, and extensive networks of bus and minibus services. Minibuses, as the name implies, are small-scale buses with around a 15-seat capacity. Dolmuş (means filled-up or full in Turkish) is a larger-scale taxi with about a 10-passenger capacity. Both systems are privatelyowned, but they are regulated by the Istanbul Municipality. Minibuses and dolmuş run on established routes with undetermined schedules, waiting for departure at the origin until the vehicle is full. Minibuses pick up passengers en route, but Dolmuş run mainly non-stop between origin and destination.

Metro (subway) construction has been protracted over the years. This results from the historic nature of the city, the desire to protect artifacts that are often uncovered by subway construction, and limits to available funding. Therefore, emphasis was placed on less expensive alternatives such as light rail lines and, later, Metrobüs BRT to reduce the long journey times.

\section{Metrobüs Development}

IETT opened its BRT system, Metrobüs, for service in 2007. A median busway with center island stations was built within the median of the freeway D100 by removing a travel lane in each direction. Bus operation is counter-flow to reduce costs and implementation times and uses conventional buses with right-hand doors. The entire Metrobüs system has a dedicated right-of-way except for the mixed traffic operations on the Bosporus Bridge.

Metrobüs has been progressively expanded through a four-phase implementation plan. Figure 1 shows the three completed phases of Metrobüs system and the fourth phase that is under construction. 


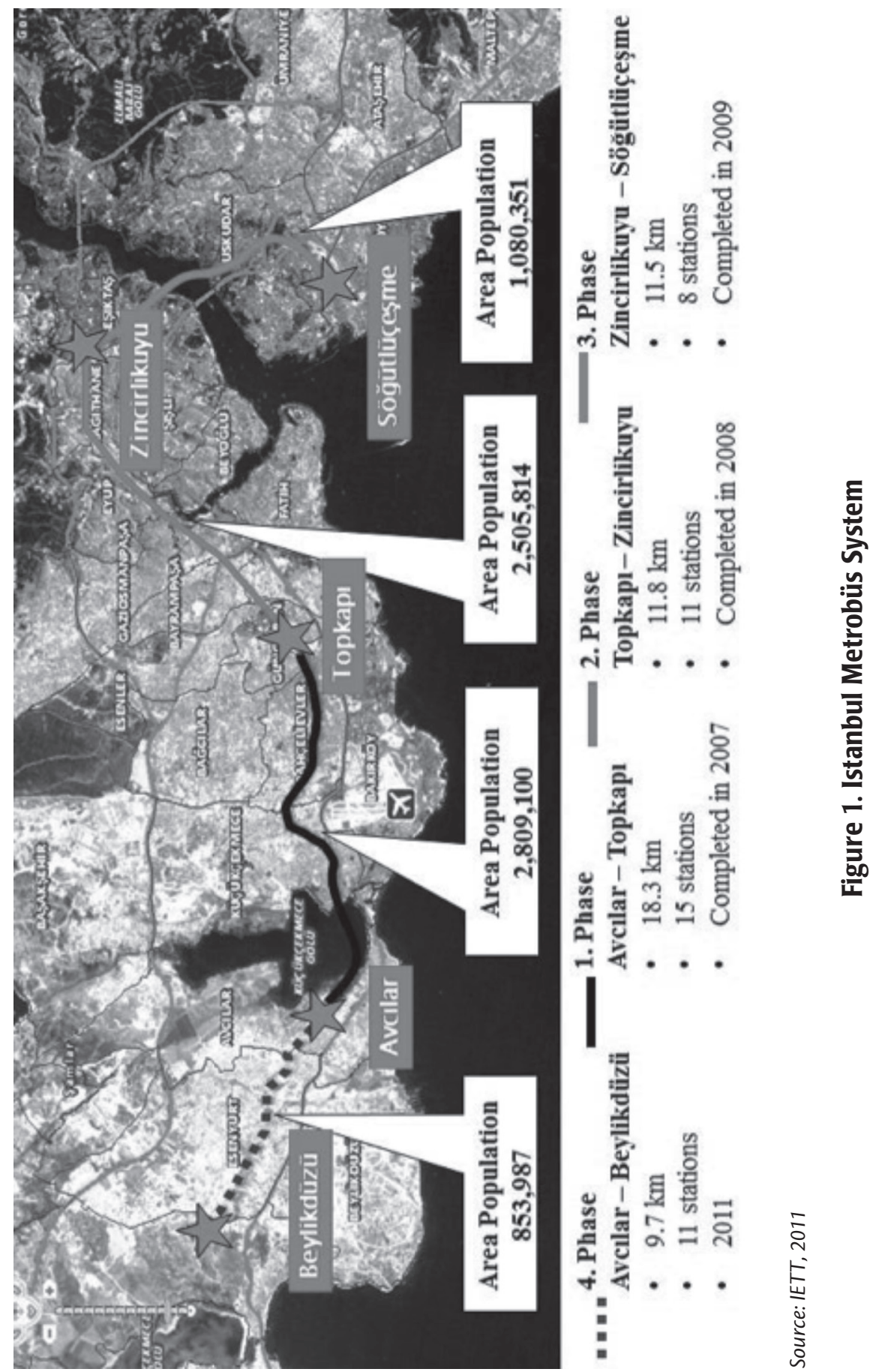


Phase 1 of Metrobüs BRT corridor development between Avcilar and Topkapi started operation on September 17, 2007, after a construction period of eight months, and is the first BRT line in Turkey. The buses run in completed gradeseparated, dedicated median lanes with no grade crossings.

Phase 2 started operations on September 8, 2008, after 77 days of construction. This construction period of less than three months is a clear example of the rapid implementation of BRT service. In Phase 2, Metrobüs started serving the main business district, which is adjacent to the highway right-of- way that is unused by Metrobüs. This increased public acceptance and ridership.

Phase 3 opened on March 3, 2009, after a construction period of only five months. It provides BRT service between the European and Asian parts of Istanbul, making Metrobüs the first and only intercontinental BRT line in the world. Buses use the Bogazici (Bosporus) Bridge to cross over the Bosporus Strait. Istanbul's Metrobüs system runs on dedicated lanes everywhere except across the Bosporus Bridge. In close proximity to the bridge entrance, buses run on dedicated lanes, merge with bridge traffic via underpasses as they enter the bridge, and continue on the dedicated lanes after exiting the bridge (Figure 2). By having dedicated lanes almost to the bridge, Metrobüs vehicles bypass the general traffic queues on either side.

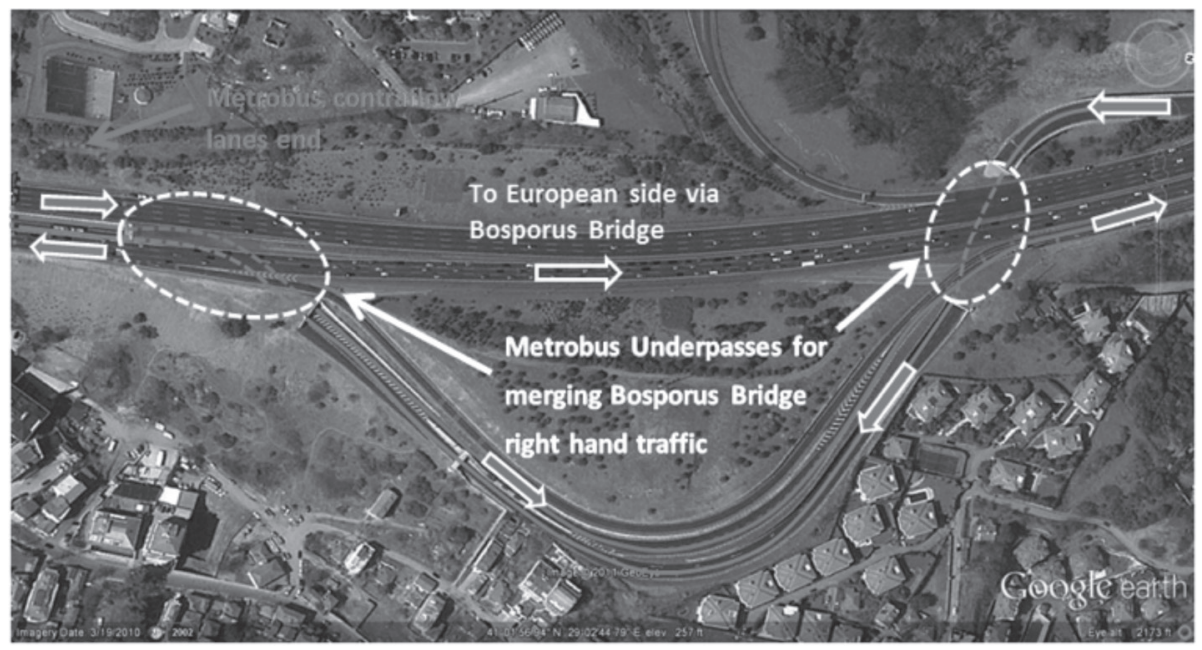

\section{Figure 2. Merging of Metrobüs median contraflow to mixed right-hand traffic on Bosporus Bridge}

Construction of Phase 4 started on March 15, 2011, and was scheduled to be completed by early 2012, but was not completed until July 19, 2012, after constructions 
delays. Phase 4 increased the system length from 42 to $51.3 \mathrm{~km}$. The cost of the project was stated as $\$ 366$ million for 3 phases, which translates to around $\$ 9$ million per km (Istanbul Metropolitan Municipality press release, March 15, 2011). This corresponds to approximately $\$ 466$ million total project cost after the last phase is completed.

Metrobüs started with about 3,250,000 monthly riders in January 2008; in May 2011 , it served $17,300,000$ passengers. These ridership numbers represent a 530 percent increase in less than 3.5 years. These ridership volumes make Metrobüs one of the most used BRT systems in the world. Thus, Metrobüs has become an essential part of Istanbul's rapid transit system and provides effective BRT operation.

\section{Design Features}

Metrobüs operates on a transitway built in the center of a freeway. Operation is contra-flow with conventional buses with right-hand doors and center platform stations and is within a constraint right-of-way. The bus lanes are physically separated from the adjacent general-purpose lanes in each direction. Grade separated U-turn roadways are provided at key locations to enable buses to change direction. Buses operate in mixed traffic over the Bosporus Bridge, but they are given priority access.

Center island station platforms provide passenger loading and alighting. The platforms extend beyond the actual bus berths to provide space for off-vehicle fare collection and bus queuing space and connect with overhead passenger ways that span the busway and general purpose travel lanes. The platforms are connected to the overhead pedestrian bridges by stairs and elevators. Figure 3 shows some snapshots of Metrobüs transitway lanes and stations.

\section{Bus Types}

The Metrobüs system uses three types of articulated buses (Table 1). All buses have four right-hand doors to expedite passenger boarding and alighting. As shown in Table 1, the vehicles were specified to meet Euro-III and Euro-IV emission standards (see http://www.dieselnet.com/standards/eu/hd.phpfor specification details) and to provide universal access. Metrobüs vehicles also provide in-vehicle passenger information screens and air conditioning. Table 1 presents salient features of the three buses as reported by IETT. The IETT's passenger capacity estimates assume crush load conditions that are higher than those used elsewhere. 


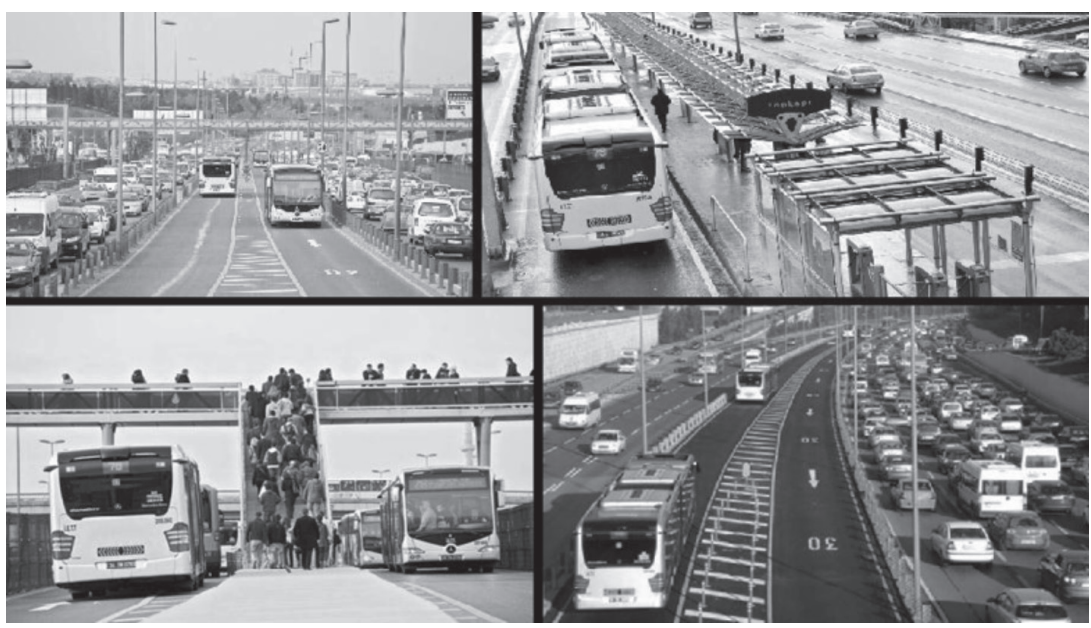

Source: IETT, 2011

Figure 3. Snapshots from Istanbul's Metrobüs system

Table 1. Summary of Bus Features, Metrobüs System

\begin{tabular}{|l|c|c|c|}
\hline \multirow{2}{*}{ Features } & \multicolumn{3}{c|}{ Manufacturer, Model } \\
\cline { 2 - 4 } & Evo Capacity & Evo Citero & ATC Phileas \\
\hline Number of vehicles & 250 & 50 & 50 \\
\hline Length & 19.5 meters & 18 meters & 26 meters \\
\hline Width & 2.55 meters & 2.55 meters & 2.55 meters \\
\hline Height & 2.95 meters & 3.16 meters & 3.08 meters \\
\hline Number of doors & 4 & 4 & 4 \\
\hline Propulsion system & Diesel & Diesel & Diesel \\
\hline Emission standards & Euro IV & Euro III & Euro III \\
\hline Handicapped access & Available & Available & Available \\
\hline Crush passenger capacity & 193 & 136 & 230 \\
\hline
\end{tabular}

Source: Istanbul Metropolitan Municipality Department of Transportation, 2011

\section{Service and Operations Plan}

The five different Metrobüs routes are shown in Figure 4. Each route has its own span of service and service area. Routes 34 and $34 \mathrm{~T}$ operate 24 hours a day, and $34 \mathrm{Z}$ runs from $\sim 5: 30$ to $\sim 2: 00 \mathrm{am}$. Route $34 \mathrm{~A}$ runs only during peak hours. Route $34 \mathrm{G}$ runs from $\sim 5: 00$ to $\sim 2: 00 \mathrm{pm}$ and 1:00 to 5:00am with less frequent service. 


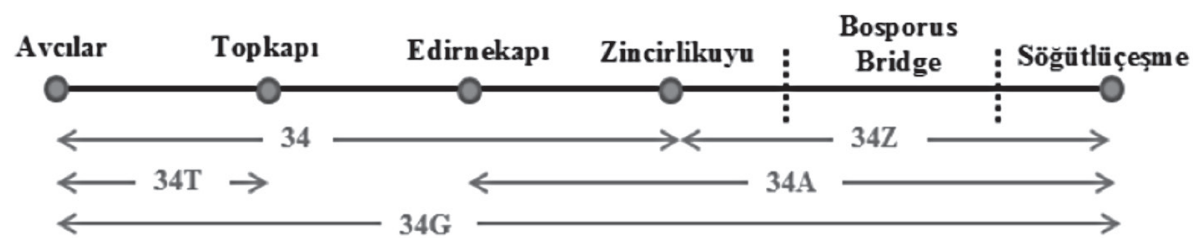

\section{Figure 4. Metrobüs routes}

An overall summary of Metrobüs operations is given in Table 2. Buses operate at 15- to 20-second intervals at the maximum service point during peak hours, 45- to 60 -second intervals all day, and every 30 minutes overnight. The maximum trip time between terminals for the $42-\mathrm{km}$ line is 63 minutes, an average of $40 \mathrm{~km} /$ hour. IETT reports the maximum passenger volume as 30,000 passengers per hour per direction. This figure assumes around 125 passengers for each bus with 15 -second service intervals, ignoring dwell times. Although high passenger occupancies are achieved during peak hours, the cited volume of 30,000 passengers per hour per direction is difficult to achieve within the current bus fleet and service frequency. Such volumes could be possible with double articulated buses (such as the ATC Phileas; see Table 1); however, these buses constitute a minor percentage of the total fleet. Hidalgo (2008) has estimated the maximum ridership at about 18,000 persons per hour in the peak direction; this passenger volume is more realistic in terms of the passengers per bus and service frequency.

\section{Table 2. Summary of Metrobüs Facts}

\begin{tabular}{|l|l|}
\hline Maximum load point, peak hour, peak direction passenger volume & $\mathbf{3 0 , 0 0 0 / h r ~ p e r ~ d i r e c t i o n ~}$ \\
\hline Daily passenger volume & 600,000 \\
\hline Number of vehicle/service trips & 3,300 trips per day \\
\hline Peak-hour frequency & $15-20$ seconds \\
\hline Off-peak-hour frequency & $45-60$ seconds \\
\hline Night (1:00-5:00 PM) frequency & 30 minutes \\
\hline Maximum terminal to terminal trip time between (max) & 63 minutes \\
\hline Total length of the Metrobüs transitway & $42 \mathrm{~km}$ \\
\hline Total number of vehicles & 315 \\
\hline Total number of stops/stations & 33 \\
\hline Average distance between stops/stations & $1.2 \mathrm{~km}$ \\
\hline Maximum service operating hours & $24 / 7$ \\
\hline Total number of staff & 845 \\
\hline
\end{tabular}

Source: Istanbul Metropolitan Municipality Department of Transportation, 2011 


\section{Ridership}

Metrobüs ridership has increased substantially since its opening in 2007. Figure 5 shows the upward trend from January 2008 to May 2011.

\section{Metrobüs Monthly Ridership}

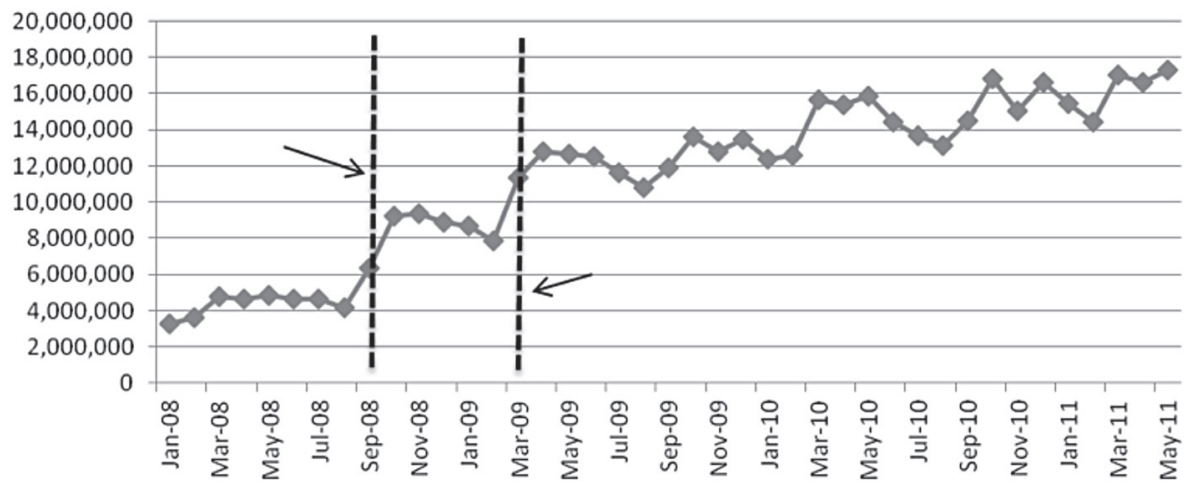

Source: Istanbul Metropolitan Municipality Department of Transportation, 2011

\section{Figure 5. Metrobüs ridership trend, January 2008-May 2011}

Table 3 shows that an average passenger trip covers about 12 stops. Assuming equally-spaced stops along the existing line, the 12 stops translate to around 15 $\mathrm{km}$ as the average distance that passengers travel on Metrobüs itself, not counting feeders/access-egress modes (IETT 2010).

\section{Table 3. Average Number of Stops Traveled for Each Metrobüs Trip}

\begin{tabular}{|c|c|c|c|c|}
\hline $\begin{array}{l}\text { Number of } \\
\text { Stops Traveled }\end{array}$ & $\begin{array}{l}\text { Number of } \\
\text { Responses }\end{array}$ & Percentage & $\begin{array}{l}\text { Cumulative } \\
\text { Percentage }\end{array}$ & $\begin{array}{l}\text { Average Number } \\
\text { of Stops Traveled }\end{array}$ \\
\hline $1-3$ stops & 86 & 7.7 & 7.7 & \multirow{8}{*}{11.9} \\
\hline 4-6 stops & 175 & 15.6 & 23.3 & \\
\hline 7-9 stops & 234 & 20.9 & 44.2 & \\
\hline $10-12$ stops & 164 & 14.6 & 58.8 & \\
\hline $13-15$ stops & 150 & 13.4 & 72.2 & \\
\hline $16-19$ stops & 122 & 10.9 & 83.1 & \\
\hline $20-22$ stops & 87 & 7.8 & 90.8 & \\
\hline$>23$ stops & 103 & 9.2 & 100.0 & \\
\hline Total & 1,121 & 100.0 & 100.0 & \\
\hline
\end{tabular}

Source: IETT, 2010 
As shown in Figure 5, opening of each phase immediately increased the number of riders. This suggests the high public acceptance and popularity of Metrobüs system.

Reasons for riding Metrobüs are shown in Table 4. High operating speed and congestion-free travel account for about 40 percent of the reasons cited for choosing Metrobüs. Comfortable travel and high frequency of service were reported as other major reasons (each about 7\%). Economic advantages and 24/7 operation both received about 2 percent. About 10 percent of the passengers say "they have to" ride Metrobüs but their reasons are not given. Overall, about 80 percent of Metrobüs users are attracted to the system because of its speed, congestion-free operations, and reliability.

Table 4. Factors Affecting Metrobüs Mode Choice

\begin{tabular}{|l|c|c|}
\hline Reasons for Using Metrobüs & Frequency (Multiple Selections) & $\%$ \\
\hline Fast & 731 & 35.9 \\
\hline No traffic congestion & 730 & 35.9 \\
\hline Comfortable & 149 & 7.3 \\
\hline Economical/cheap & 44 & 2.2 \\
\hline Frequent service & 132 & 6.5 \\
\hline I have to ... & 201 & 9.9 \\
\hline Runs 24 hours & 44 & 2.2 \\
\hline Safety/security & 3 & 0.1 \\
\hline Total & 2034 & 100.0 \\
\hline
\end{tabular}

Source: IETT, 2010

Monthly ridership trends are shown in Figure 5. Ridership continues to increase, especially after the BRT service was extended. There are some slight variations in ridership between the spring/summer and fall/winter months.

A Metrobüs research report (IETT 2010) shows that boarding passengers sometimes wait for several buses until the arrival of a bus that is not already full. Considering the very frequent peak-hour service, this suggests that Metrobüs system operates at full (or near-full) capacity during peak hours.

\section{Trip Purposes and Demographics}

Table 5 summarizes Metrobüs passenger trip purposes based on gender and age. It shows that most Metrobüs trips are made for work or school purposes ( $54 \%)$. Among younger age groups, school trips have the highest percentage. For middle- 
age/working-class-age groups, home/work commute has the highest trip purpose share. The 65+ age group uses Metrobüs heavily for health-related trips (49.2\%), e.g., doctor or hospital, and for socializing purposes, e.g., family/friend visits, with a share of 29.2 percent. In countries with low car ownership such as Turkey, the older adult population's means of travel becomes an important concern. Istanbul's Metrobüs offers a reliable and safe travel mode alternative for Istanbul's older adult population.

Table 5. Trip Purposes vs. Demographics of Metrobüs Users

\begin{tabular}{|l|c|c|c|c|c|c|c|c|c|c|}
\hline \multirow{2}{*}{\begin{tabular}{l} 
Metrobüs \\
$\begin{array}{l}\text { Trip } \\
\text { Purpose } \\
\text { (\%) }\end{array}$ \\
\cline { 2 - 12 }
\end{tabular}} & \multicolumn{7}{|c|}{ Gender } & \multicolumn{7}{|c|}{ Age Group } & \multirow{2}{*}{ Overall } \\
\cline { 2 - 11 } & Female & Male & $15-18$ & $19-24$ & $25-34$ & $35-44$ & $45-54$ & $55-64$ & $65+$ & \\
\hline $\begin{array}{l}\text { From/to } \\
\text { home/ } \\
\text { work }\end{array}$ & 31.5 & 44.6 & 5.0 & 20.3 & 51.3 & 60.8 & 43.4 & 22.5 & 3.1 & 38.2 \\
\hline $\begin{array}{l}\text { From/to } \\
\text { home/ } \\
\text { school }\end{array}$ & 22.0 & 10.5 & 68.0 & 50.0 & 10.1 & 0.9 & 0.6 & 0 & 1.5 & 16.1 \\
\hline $\begin{array}{l}\text { Shopping } \\
\text { Business }\end{array}$ & 10.6 & 4.6 & 5.0 & 3.8 & 8.1 & 5.6 & 12.7 & 8.8 & 9.2 & 7.5 \\
\hline $\begin{array}{l}\text { Entertain- } \\
\text { ment/ } \\
\text { social } \\
\text { activities }\end{array}$ & 9.5 & 8.0 & 9.0 & 10.8 & 8.1 & 7.3 & 7.8 & 12.7 & 7.7 & 8.7 \\
\hline $\begin{array}{l}\text { Hospital/ } \\
\text { doctor/ } \\
\text { health } \\
\text { services }\end{array}$ & 6.2 & 8.4 & 2.0 & 2.5 & 1.0 & 3.9 & 7.2 & 19.6 & 49.2 & 7.3 \\
\hline $\begin{array}{l}\text { Friend/ } \\
\text { family visit }\end{array}$ & 16.2 & 15.9 & 10.0 & 9.5 & 14.8 & 10.8 & 21.1 & 31.4 & 29.2 & 16.1 \\
\hline \begin{tabular}{l} 
Total \\
\hline
\end{tabular} & 100 & 100 & 100 & 100 & 100 & 100 & 100 & 100 & 100 & 100 \\
\hline
\end{tabular}

Source: IETT, 2010

The percentages of trip purposes also reflect the frequency of Metrobüs use (Table 6). About 29 percent of the surveyed passengers ride Metrobüs every day and 25 percent ride every weekday. An interesting finding is the share of "rarely" users (10\%). This percentage suggests that despite the relatively short history of BRT in Istanbul, the public is well aware of the Metrobüs system and occasional riders understand how to use Metrobüs in terms of access points, routing, and schedules. 
Table 6. Frequency of Metrobüs Use

\begin{tabular}{|l|c|c|}
\hline Frequency & \# of Responses & \% \\
\hline Every day & 326 & 29.1 \\
\hline Every weekday & 283 & 25.3 \\
\hline Once in 2-3 days & 172 & 15.3 \\
\hline Only weekends & 73 & 6.5 \\
\hline Once a week & 116 & 10.3 \\
\hline Once in 2 weeks & 30 & 2.7 \\
\hline Rarely & 121 & 10.8 \\
\hline Total & 1,121 & 100.0 \\
\hline
\end{tabular}

Source: IETT, 2010

Survey respondents were divided into five groups, based on household incomes and education level: A (Top), B (Upper), C1 (Upper Middle), C2 (Lower Middle), and $\mathrm{DE}$ (Bottom) socio-economic status. The survey findings show that Metrobüs users mainly belong to DE (30.6\%) or C2 (30.1\%) status. Category A constitutes 2.6 percent, followed by categories B (17.4\%) and C1 (39.3\%). Overall, the Metrobüs system is used mainly by low-income groups who are less likely to have access to a private vehicle. Given the relatively low Metrobüs fare, the system plays an important role in term of transportation equity.

\section{Accessibility, Integration with Other Modes, and Modal Shift}

Metrobüs connects with regular IETT bus, subway, and light rail systems. IETT encourages multimodal trips by offering free transfers between Metrobüs and other modes. Metrobüs also provides accessibility to the Ataturk Airport (Istanbul's largest airport) by connecting with a light rail system that goes directly to the airport.

Access modes to Metrobüs stations are shown in Table 7. A large share (37\%) of Metrobüs riders walks to and from Metrobüs to reach their destinations. Most walking takes less than 10 minutes, and the share of walking is higher for egress from Metrobüs. The second highest access mode is dolmuş/minibus, followed by regular IETT buses. The high share of walking shows that the Metrobüs mainly serves people living or working near Metrobüs stations. The high share of regular IETT buses and dolmuş/minibus access shows that these modes function as important feeders to the Metrobüs system. However, there is no special infrastructure available to make transfers easy to and from Metrobüs. 
Table 7. Access Modes to Metrobüs and Mode Choice Before Metrobüs

\begin{tabular}{|l|c|c|c|c|}
\hline \multicolumn{1}{|c|}{ Access Mode } & $\begin{array}{c}\text { Transfer to } \\
\text { Metrobüs (\%) }\end{array}$ & $\begin{array}{c}\text { Transfer from } \\
\text { Metrobüs (\%) }\end{array}$ & $\begin{array}{c}\text { Average } \\
\text { Access } \\
\text { Share (\%) }\end{array}$ & $\begin{array}{c}\text { Travel Mode for } \\
\text { Same Trip Before } \\
\text { Metrobüs (\%) }\end{array}$ \\
\cline { 1 - 4 } Walk (less than 10 mins) & 27.8 & 32.4 & 30.1 & \multirow{2}{*}{1.8} \\
\cline { 1 - 4 } Walk (more than 10 mins) & 7.0 & 6.9 & 6.9 & \multirow{2}{*}{6.1} \\
\hline Tram/subway & 3.5 & 6.0 & 4.7 & 55.7 \\
\hline IETT bus & 22.0 & 19.1 & 20.6 & 18.1 \\
\hline Private public bus & 9.0 & 8.0 & 8.5 & 0.7 \\
\hline Commuter rail & 0.3 & 0.2 & 0.3 & 0.4 \\
\hline Service buses & 0.2 & 0.4 & 0.3 & 4.0 \\
\hline Private car & 1.3 & 0.3 & 0.8 & 9.4 \\
\hline Dolmuş/minibus & 25.5 & 21.1 & 23.3 & 1.0 \\
\hline Taxi & 3.4 & 5.6 & 4.5 & 97.2 \\
\hline Total & 100.0 & 100.0 & 100.0 & \\
\hline
\end{tabular}

Source: IETT, 2010

On the other hand, the share of tram/subway access is barely above the share of taxi. This suggests a need for additional planning and incentives for Metrobüs-rail integration. Nevertheless, the survey results show that almost 30 percent of passengers reach their destination within 20 minutes, about 58 percent reach within half an hour, and 96.2 percent before one hour.

Table 7 also shows the previous travel modes of Metrobüs riders for the same trip before Metrobüs was available. In addition to the modes shown in Table 7, another 1.8 percent of the passengers reported maritime transportation (ferries, catamaran-type sea buses, etc.) as their previous travel mode. Another one percent of passengers reported that they did not make their trip before Metrobüs was implemented.

The highest level of modal shift is from regular IETT buses (55.7\%), followed by private public buses (18.1\%) and dolmuş/minibus (9.4\%). In other words, the Metrobüs system draws its users mainly from previous bus riders. However, this modal shift should be interpreted with caution. IETT and Istanbul Municipality adjusted several IETT private/public bus and minibus lines and schedules after the start of BRT operations. Eighteen lines were canceled, and 11 were shortened. Hence, the modal shifts from regular buses are not necessarily by choice, but they also reflect changes in the public transit network. On the other hand, four percent of passengers report 
shifting from private car and taxi to Metrobüs and almost seven percent from various rail modes. This shift from car and taxi travel to Metrobüs suggests a high level of convenience offered by Metrobüs, while for the seven percent shifting from urban rail (metro, light rail, commuter rail), it shows that the Metrobüs alternative provides a more convenient service for those riders.

\section{Benefits and Savings}

The reported Metrobüs project savings for operator, passengers, and the environment are summarized in Table 8. On the operator side, Metrobüs helped IEET to remove 113 IETT and 76 private buses. A total of 1,296 minibuses were also removed from street traffic and the passengers were directed to Metrobüs. IETT canceled and shortened some bus lines as the Metrobüs system was extended, but some lines were reported to be reinstated due to demand from passengers. Overall, 18 bus lines were canceled (mainly the ones that cross the Bosporus) and 11 were shortened. As a result, in addition to lower operating and maintenance costs compared to standard bus operations, 242 tons of daily fuel savings were reported. The fuel saving translates to 623 tons of reduction in daily $\mathrm{CO}_{2}$ emissions.

\section{Table 8. Summary of Savings/Benefits after Introduction of Metrobüs}

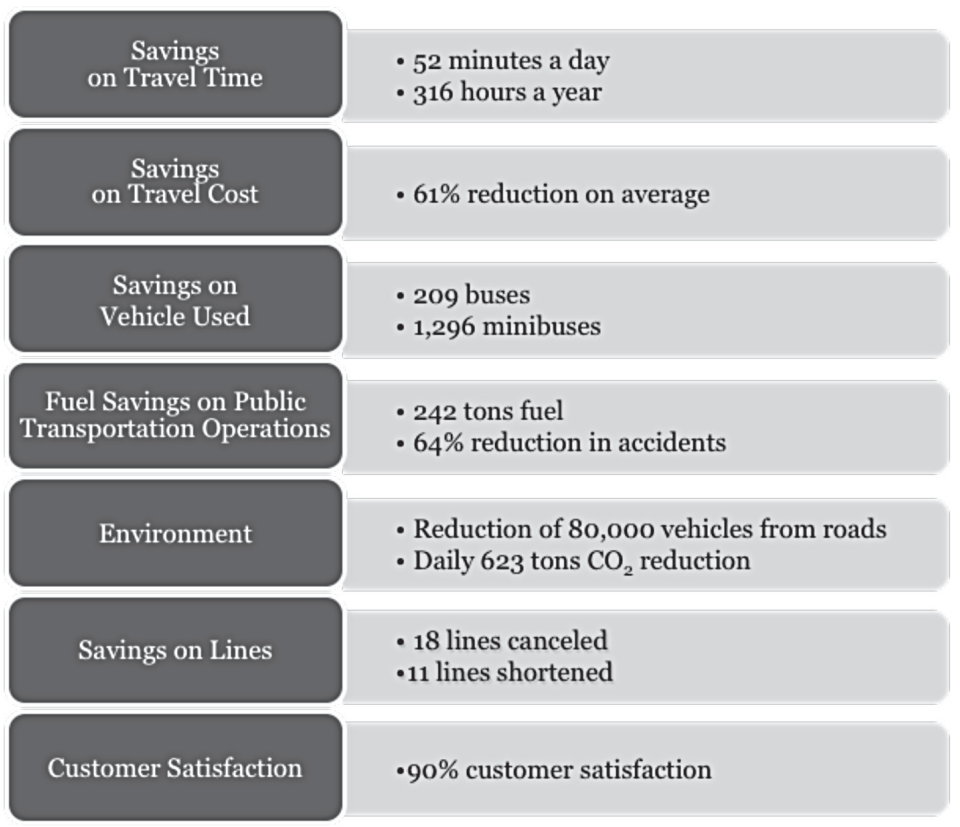

Source: Istanbul Metropolitan Municipality, Department of Transportation, 2011 
Operating fewer buses in city traffic and more buses in dedicated and thus safer lanes achieved a 64 percent reduction in accidents (IETT 2011). The Metrobüs passenger survey found that more than 87 percent of Metrobüs ridership came from other road vehicles (private car, taxi, private bus, regular bus, minibu, dolmuş), including 4 percent of car users who switched to Metrobüs. Hence, Metrobüs encourages greater use of a safer public transportation mode.

The uninterrupted bus flow in dedicated rights-of-way allows the operator to adjust services based on changes in passenger density and demand. Boarding a Metrobüs bus is more efficient than boarding a regular bus because the fare is paid before entering the station area and the tickets are not collected inside the bus. This makes all bus doors available for passenger boarding movements, thereby reducing dwell times and increasing efficiency. Furthermore, the predictability of bus arrivals and the restricted access to bus stops make it possible to provide reliable passenger information displays and use advanced fare collection technologies.

From the passenger perspective, Metrobüs guarantees fast, safe, and reliable ontime travel. There was a recent fare increase throughout the IETT-managed public transportation system, including Metrobus, effective by September 1, 2012. Before the increase, Metrobüs charged 1.45 Turkish Liras (TL) for an adult fare for up to 3 stops of travel and 2.10TL for traveling more than 3 stops. After the increase, IETT also changed the Metrobüs fare structure to be distance-based. Currently, Metrobus charges 1.60TL for an adult fare for up to 3 stops of travel, 2.40TL for traveling more between 3-9 stops, and 0.10TL for more for each additional 6 stops up to 39 stops, e.g., 2.50TL for 10-15 stops, 2.60TL for 16-21 stops, and so on. The maximum fare is $2.95 \mathrm{TL}$ for $\mathbf{4 0}$ more stops. IETT offers discounted student fares and other discounted fares for older adults, teachers, and so on. Student fares were kept the same after the last increase, paying flat fare of 1.00TL for more than 3 stops.

Integration with other transportation modes allows additional time savings. However, the main cost saving arises because regular bus lines that cross the Bosporus charge double fare, whereas Metrobüs does not. Hidalgo and Bulay (2008) estimated 31.5 minutes per passenger travel time savings in 2008 following the opening of the Metrobüs line. As of 2011, IETT reported an average of 52 minutes of daily travel time savings per passenger, which corresponds to 316 hours of yearly travel time reduction per user. Table 9 shows the travel time savings for Avcilar and Sogutlucesme (see Figure 1) travel and fare savings for short- and long-distance trips for different fare categories. IETT reported average passenger cost savings of 61 percent before the September 2012 fare increase and opening of Phase 4. As 
shown in Table 9, the average savings per passenger could be less than 61 percent based on the distance traveled with Metrobüs.

\section{Table 9. Travel Time and Fare Savings with Metrobüs}

\begin{tabular}{|l|l|c|c|c|c|c|}
\cline { 2 - 7 } \multicolumn{1}{l|}{} & Travel without Metrobüs & Travel with Metrobüs & \multicolumn{2}{c|}{ Savings (+) } \\
\hline $\begin{array}{l}\text { Start to end } \\
\text { travel time } \\
\text { (mins) }\end{array}$ & \multicolumn{2}{|c|}{180} & \multicolumn{2}{c|}{63} & \multicolumn{2}{c|}{$65 \%$} \\
\hline Fare Type (TL) & Before & After & Before & After & Before & After \\
\hline Adult & $\begin{array}{c}5.25(4.50 \\
\text { discounted } \\
\text { transfer) }\end{array}$ & $\begin{array}{c}5.85(5.15 \\
\text { discounted } \\
\text { transfer) }\end{array}$ & 2.10 & $2.40-2.95$ & $\begin{array}{c}60 \%(53 \% \\
\text { discounted } \\
\text { transfer) }\end{array}$ & $\begin{array}{c}50-59 \% \\
(43-53 \% \\
\text { discounted } \\
\text { transfer) }\end{array}$ \\
\hline Student & $\begin{array}{c}3.00(2.75 \\
\text { discounted } \\
\text { transfer) }\end{array}$ & $\begin{array}{c}3.00(2.75 \\
\text { discounted } \\
\text { transfer) }\end{array}$ & 1.00 & 1.00 & $\begin{array}{c}67 \%(64 \% \\
\text { discounted } \\
\text { transfer) }\end{array}$ & $\begin{array}{c}67 \%(64 \% \\
\text { discounted } \\
\text { transfer) }\end{array}$ \\
\hline Discounted & $\begin{array}{c}3.60(3.00 \\
\text { discounted } \\
\text { transfer) }\end{array}$ & $\begin{array}{c}4.05(3.45 \\
\text { discounted } \\
\text { transfer) }\end{array}$ & 1.20 & $1.40-1.60$ & $\begin{array}{c}67 \%(60 \% \\
\text { discounted } \\
\text { transfer) }\end{array}$ & $\begin{array}{c}60 \%-65 \% \\
(54 \%-59 \% \\
\text { discounted } \\
\text { transfer) }\end{array}$ \\
\hline $\begin{array}{l}\text { Short Distance } \\
\text { Adult }\end{array}$ & 1.75 & 1.95 & 1.45 & 1.60 & $17 \%$ & $18 \%$ \\
\hline $\begin{array}{l}\text { Short Distance } \\
\text { Student }\end{array}$ & 1.00 & 1.00 & 0.85 & 0.85 & $15 \%$ & $15 \%$ \\
\hline $\begin{array}{l}\text { Short Distance } \\
\text { Discounted }\end{array}$ & 1.20 & 1.35 & 1.00 & 1.15 & $17 \%$ & $15 \%$ \\
\hline
\end{tabular}

Source: IETT, 2011

\section{Passenger Satisfaction}

IETT's Metrobüs passenger survey includes a long section on passenger satisfaction. Satisfaction levels are categorized as "Not satisfied at all," "Unsatisfied," "Neither satisfied nor unsatisfied," "Satisfied," and "Very satisfied." The survey findings show that Istanbul residents report a 58 percent positive response ("Satisfied" and "Very satisfied") for overall satisfaction. Negative responses ("Not satisfied at all" and "Unsatisfied") constitute only 5 percent, with the remaining 36 percent being neutral ("Neither satisfied nor unsatisfied"). Similar positive reception rates are also valid for specific facility and trip concerns. For example, Metrobüs travel time, 
passenger waiting time, and trip frequency received 56,45 , and 49 percent positive responses, respectively, as compared to 5,13 , and 16 percent negative responses.

The least satisfaction is reported for Metrobüs trip costs and crowding of buses. The survey reports that 31 percent of the passengers are "Satisfied" or "Very satisfied" with the travel cost, whereas 41 percent of the passengers are either "Not satisfied at all" or "Unsatisfied," and 28 percent are "Neither satisfied nor unsatisfied."

Two questions in the survey provide important information regarding mode choice. In the first question, respondents were asked about their satisfaction with Metrobüs travel time compared to making the same trip with another public transportation mode. In the second question, the same comparison was asked for the same trip using a private vehicle or taxi. Most of the passengers responding to the first question (57.9\%) favored Metrobüs rather than other public transportation modes, 35.7 percent were neutral, and only 6.4 percent were negative. The responses to the second question showed that even a higher percentage of Metrobüs users (64.4\%) favored Metrobüs over making the same trip in a private vehicle or taxi, with only 4.5 percent giving negative responses. These two responses indicate that the higher speed and reliability of Metrobüs travel on dedicated lanes has the potential to alter the mode choice of travelers, including the shifts from private vehicles to public transportation.

\section{Comparison of Metrobüs with Other BRT Systems Worldwide}

Although Metrobüs has a relatively short history, it is one of the most highlyused BRT systems in the world. This is apparent from Figure 6, which compares Metrobüs with other BRT lines. Currently, Metrobüs carries approximately 600,000-800,000 passengers per day (EMBARQ 2011). Bogota's multi-line TransMilenio serves $1,600,000$ passengers per day and has the highest total number of passengers, followed by Metrobüs. On the other hand, TransMilenio has 1,027 passenger boardings per bus per day compared to Metrobüs's 2,255 boardings per bus per day. Guayaquil's Metrovia and Guadajalara's Macrobus have the highest number of passenger boardings per bus per day (Hidalgo and Carrigan 2010).

Bogotá has the highest total cost (infrastructure plus equipment) at \$12.5 million per $\mathbf{k m}$, and Istanbul's Metrobüs has the second highest cost at $\$ 8.9$ million. In terms of commercial speed, Metrobüs operates at $40 \mathrm{~km} / \mathrm{hr}$, followed by Bogotá's TransMilenio at $28 \mathrm{~km} / \mathrm{hr}$ commercial speed (Hidalgo and Carrigan 2010). On the other hand, based on year 2009 user fares, Metrobüs charges slightly lower fares/ 


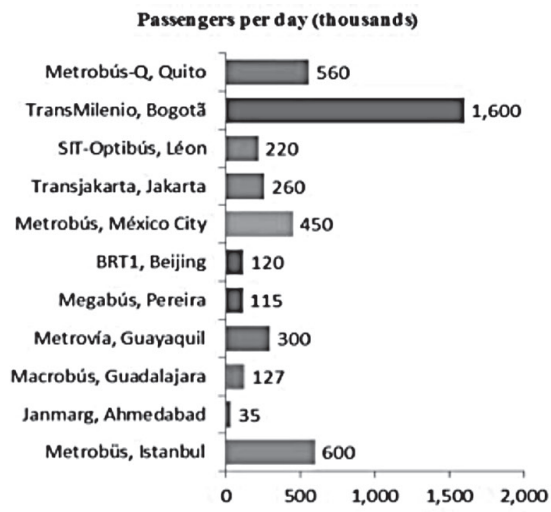

Total cost (In frastructu re + equipment) per km (S Millions)

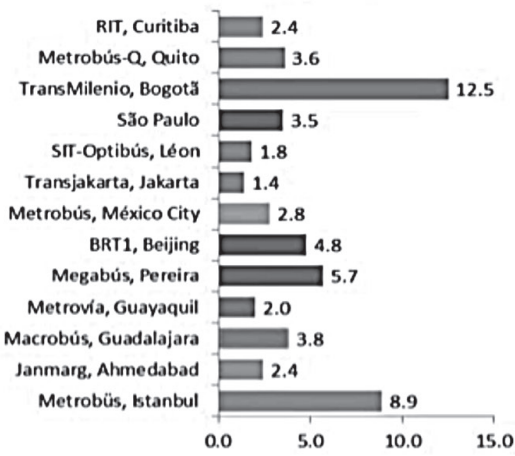

\section{Passenger Boarding per bus per day}

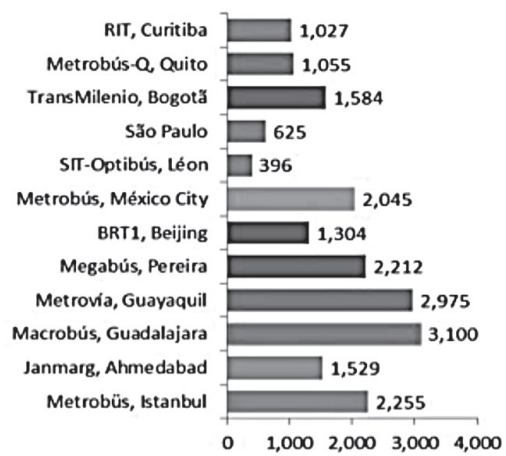

Commercial speeds $(\mathbf{k m} / \mathbf{h})$

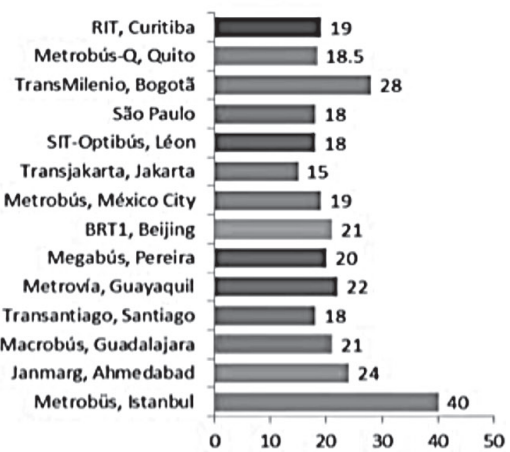

User Fares

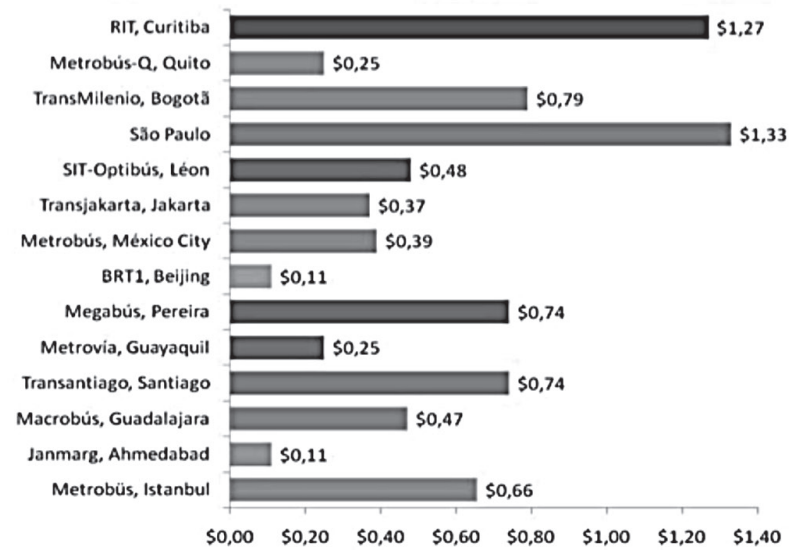

Sources: Hidalgo and Carrigan, 2010; Istanbul Metropolitan Municipality, Department of Transportation, 2011

\section{Figure 6. Comparison of Metrobüs and other BRT systems worldwide}


$\mathrm{km}$ than the worldwide average. Overall, since starting its operations, Metrobüs has earned high rankings compared to other BRT systems in the world.

\section{Conclusions, Concerns and Possible Improvements}

The long history of civilization in Istanbul raises the challenge of dealing with the built environment in transportation planning. For instance, construction of the Istanbul subway was stopped several times by the discovery of new archeological sites during excavations (Landler 2005). There also had been fatality incidents due to failures at structures above subway construction (NTVMSNBC 2011). Another structure failure at the French Consulate resulted in a court case that suspended the project (Hurriyet 2000). The slow progress of subway construction led to placing more emphasis on at-grade, surface public transport such as LRT and BRT, and several new light rail lines were constructed.

\section{Accomplishments}

Metrobüs BRT implementation can be regarded as significant transport improvement with more immediate results. Built in a few years, Metrobüs has expanded several times since its opening in 2007. Construction complexities were simplified and costs were lowered by operating in a freeway median and in mixed traffic over the Bosporus Bridge. Off-vehicle fare collection and the use of multi-door articulated buses expedite passenger boarding and allow high passenger capacity. Metrobüs is a heavily-used intercontinental BRT line that carries about 18,000 to 20,000 passengers per hour in the maximum load section per direction in the rush hour at its busiest point. This is considerably more than the passengers carried by automobile in the adjacent general purpose lanes. Thus, it dramatically increases the total person capacity of the freeway.

Considering its ridership and positive public reception, Metrobüs is a successful BRT project. The reasons for its success are summarized as follows:

- Fast, convenient, cheaper, congestion free travel: Metrobüs provides considerable time savings for passengers and offers more convenient and cheaper rides than modern buses. IETT reports average travel time savings of 52 minutes per day per passenger.

- High public transportation rider potential: Istanbul is a transit-dependent city with low car ownership. Although the forecasts anticipate rapidlyincreasing car ownership, the city's high density makes public transport a viable and essential option, even for car owners and private taxi users. 
- Politically-favored and supported: Although Metrobüs received some initial resistance, particularly from car users, the high demand for public transportation makes most transit investments in Istanbul (including BRT) politically acceptable when the new mode increases passenger convenience. The resistance from car users was not strong enough to reclaim the two general purpose lanes that were occupied by Metrobüs.

- Phased construction to balance public acceptance and available resources: Metrobüs was implemented phase by phase. This allowed assessing public response and planning accordingly. The first phase was not constructed through the middle of the business district where it would likely receive more resistance. After first phase increased ridership, the second phase was opened and the line then passed through the main business district. The third phase further reduced travel times for passengers commuting between the European and Asian sides of Istanbul.

The main concern for Phase 3 was how to sustain a high level of service across the Bosporus Bridge without dedicating lanes to BRT-whether buses using the general traffic lanes on the Bosporus Bridge would delay the Metrobüs services. However, the priority access provided on both sides of the bridge allowed Metrobüs vehicles to jump ahead of the bridge-related queues and largely eliminated the problem. Thus, a phased implementation approach helped build political and popular acceptance of Metrobüs, leading to even higher increases in ridership than otherwise would have been expected.

- High-speed, reliable alternative for intercontinental travel: There is a debate regarding BRT's effectiveness and cost compared to a light rail system alternative. However, the main problem for an uninterrupted LRT system appears to be the connection over the Bosporus. It is neither practical nor possible to add a rail system on the existing bridges that were designed without considering a rail system on the bridge.

There are plans for building a third bridge over the Bosporus in the future; however, the new bridge will not directly serve the existing commercial districts. A tunnel under the Bosporus along the Metrobüs corridor would be costly and, because of maximum permissible grades and the great depth of the sea, long approach distances would be needed. A rail line between the two sides of the strait is under construction (the Marmaray project). However, more time is needed before the underground service will be operational. A ferry system, no matter how well inte- 
grated with the rest of the public transport system on both sides of the Bosporus, would require double transfers of most passengers. Hence, Metrobüs emerged as the only viable, readily-buildable, uninterrupted travel option to increase passenger capacity and save passenger time, in both the short and medium terms. In the near- and mid-terms, Metrobüs faces no real competition from other modes and attracts a large number of passengers, especially during peak hours.

\section{Concerns}

The Metrobüs project was criticized mainly during the early stages of development. Concerns were expressed over the rush of its opening, thereby not providing sufficient design and infrastructure for large bi-articulated buses (Şişli Gazetesi 2008). Some purchased buses were not able to satisfactorily operate on steep grades (Hurriyet 2009). There was insufficient signage and lack of directions at stations. Also, there was inconvenience created by canceled regular bus lines (Cumhuriyet 2008). Controversy about the malfunctions of Phileas double-articulated buses was cited to be a major factor that increased the cost of the project (Hurriyet 2009). IETT cited the very high loading at peak hours as the reason for malfunctioning rather than the road slope and dismissed the criticisms regarding the insufficient planning (Hurriyet 2009). IETT's general manager also cited Phileas's high fuel efficiency and high passenger-loading capacity as justifications for the purchase of these buses (Sonsayfa News Site 2009).

As previously discussed, the high passenger volume capacity estimation of Metrobüs is based on high passenger capacity buses such as Phileas, which could not be fully used in Metrobüs operations due to the aforementioned technical difficulties. Nevertheless, IETT responded to the criticisms by reinstating some regular bus lines with popular demand, improved the physical appearance of Metrobüs stations, added more signage and directions, and built additional necessary infrastructure for safe bus maneuvers. On the other hand, the overall safety of Metrobüs operations was also questioned, because several accidents happened after vehicles at regular lanes crossed over to the counter-flowing Metrobüs lane and crashed with Metrobüs (Chamber of Mechanical Engineers 2011). However, IETT reports that the number of Metrobüs accidents since 2007 is significantly lower than the number of accidents previously reported for the regular bus lines that were replaced by Metrobüs.

In IETT's own evaluation, complaints from public due to traffic delays, and disruptions in commercial operations during the construction phase are highlighted. It is reported that although the infrastructure along the Metrobüs line has been 
reconstructed, the temporary service disruptions created inconvenience for the public. In addition, other public services such as garbage collection caused temporary suspensions in Metrobüs construction and consequently increased the project costs (IETT 2011).

\section{Possible Improvements}

Despite the cited concerns, Metrobüs receives very high passenger satisfaction ratings and stands as a popular and effective mode. Meanwhile, there are still opportunities for further improvements. Hidalgo and Bulay (2009) identify several key points of improvement, including efficient pedestrian access, disabled accessibility, better bus stop design and increasing capacity, and better physical transfer facilities between Metrobüs and other modes. Currently, an envisioned automatic docking system is not implemented, use of hybrid bi-articulated buses show some difficulties, and level passenger boarding has not been achieved. Better transfer facilities from/to Metrobüs from other modes are also needed for more efficient flow of passengers. Pedestrian access via overpasses works efficiently at locations with appropriate alignment; however, access for passengers with limited mobility remains a major problem. Possible system improvements include extending the Metrobüs line to the west, progressively replacing the Metrobüs fleet with bi-articulated buses, and providing more efficient pre-payment technologies. Using bi-articulated buses that provide level, no-gap boarding and alighting could substantially reduce dwell times and increase capacity. Longer-term improvements should also include providing high platform stations to be used with high platform buses and providing places en route to pass buses.

\section{In Prospect}

From a transportation planning and operations perspective, Metrobüs shows that converting general purpose freeway travel lanes to BRT use is viable where there is high passenger demand and an existing high volume of surface public transport users. The operation of Metrobüs on both dedicated lanes and in mixed traffic is consistent with BRT operations in other cities. This type of treatment uses the flexibility of BRT and can be applied to BRT systems elsewhere throughout the world (Bulay 2011). As a future research direction, analyzing socioeconomic indicators and conducting an economic cost-benefit evaluation may shed more light on the economic feasibility of Metrobüs.

\section{Acknowledgments}


The authors would like thank the Istanbul Metropolitan Municipality Department of Transportation, Istanbul Public Transport Authority (IETT) for providing the Metrobüs data used in this study. The authors would also like to thank Sam Zimmermann and Sibel Bulay for supplying complementary information and visuals about the Metrobüs system.

\section{References}

Bulay, S. 2011. Surdurulebilir ulasim politika ve projeleri. 2011 Sustainable Transport Symposium, April 6-8, Kocaeli, Turkey.

Cumhuriyet. 2008. Metrobüs: Toplu ulaşımda kaos (in Turkish). November 14. Available at http://www.cumhuriyet.com.tr/?hn=17062.

Embarq Turkey Office, Metrobüs Study Website. Available at http://www.embarq. org/en/project/istanbul-Metrobüs (last accessed September 30, 2011).

Gercek, H., and O. Demir. 2008. Urban mobility in Istanbul. Blue Plan Workshop on Urban Mobility in Istanbul, Developments and Prospects, Istanbul. Available at http://www.planbleu.org/publications/Mobilite_urbaine/lstanbul/Atelier/ Istanbul_\%20Urban_Mobility_HG.pdf(last accessed September 30, 2011).

Gunay, E. 2007. Interaction of urban fringe and transportation system: Istanbul case. M.S. Thesis, Izmir Institute of Technology. Available at http://library.iyte. edu.tr/tezler/master/sehirplanlama/T000697.pdf (last accessed September 30, 2011).

Hidalgo, D., and A. Carrigan. 2010. Modernizing public transportation. Research Report, EMBARQ, World Resources Institute's Center for Sustainable Transport. Available at http://pdf.wri.org/modernizing_public_transportation.pdf (last accessed September 30, 2011).

Hidalgo, D., and S. Bulay. 2009. Istanbul Metrobus BRT. Adapted from Presentations by World Resources Institute/EMBARQ. Available at http://siteresources. worldbank.org/AZERBAIJANEXTN/Resources/301913-1241195959430/E05b. pdf.

Hidalgo, D., and S. Bulay. 2008. Istanbul Metrobüs, a high performance BRT system. Preliminary Evaluation, EMBARQ, the WRI Center for Sustainable Transport.

Hurriyet. 2000. Fransız Başkonsolosluğu metrodan davacı oldu (in Turkish). June 26. Available at http://webarsiv.hurriyet.com.tr/2000/06/29/218974.asp. 
Hurriyet. 2009. Expensive buses head to the garage. April 21. Available at http:// arama.hurriyet.com.tr/arsivnews.aspx?id=11474078.

Istanbul Metropolitan Municipality. 2009. Metrobüs bilet ücreti ile ilgili açiklama! (in Turkish). Media release November 16. Available at http://www.iett.gov.tr/ haber_detay.php?nid=577.

Istanbul Metropolitan Municipality, Department of Transportation. 2011.

Istanbul Metropolitan Municipality. 2011. Metrobüs dream comes true for people of Beylikdüzü. Media release March 15. Available at http://www.ibb.gov.tr/ en-US/Pages/Haber.aspx?NewsID=529.

Istanbul Public Transport Authority (IETT). 2011. Public transportation fares. Toplu taşıma ücret tarifesi (in Turkish). Available at http://www.iett.gov.tr/metin. php?no=237.

Istanbul Public Transport Authority (IETT). 2010. Metrobüs research report. Final report. IETT, Istanbul, Turkey.

Landler, Mark. 2005. A subway bores into the Ottoman and Byzantine eras. The New York Times, August 2. Available at http://www.nytimes.com/2005/08/02/ international/europe/02istanbul.html.

NTVMSNBC. 2001. İstanbul'da pansiyon çöktü: 2 ölü (in Turkish). September 19. Available at http://arsiv.ntvmsnbc.com/news/107400.asp.

Şişli Gazetesi. 2008, Metrobüs dönüşü olmayan yolda (in Turkish). May 9. Available at http://www.sisligazetesi.com.tr/guncel/metrobus-donusu-olmayan-yoldah13025.html.

Sonsayfa. 2009. IETT Müdürü iddialara rest çekti (in Turkish). May 23. Available at http://www.sonsayfa.com/Haberler/Guncel/IETT-Muduru-iddialara-restcekti-113081.html.

Turkstat, Turkish Statistical Institute, Prime Ministry, Republic of Turkey. 2010. Address based population registration system results of 2010. Available at http://www.turkstat.gov.tr/PreHaberBultenleri.do?id=8428.

Union of Chambers of Turkish Engineers and Architects, Chamber of Mechanical Engineers. 2011. Metrobüs kazalarinin sorumlusu yetkililerdir (in Turkish). Press release, December 8. Available at http://www.mmo.org.tr/genel/bizden_detay.php?kod=26633\&tipi=3\&sube $=10$. 
www.diesel.net. European Union emission standards for heavy duty diesel truck and bus engines. Available at http://www.dieselnet.com/standards/eu/hd.php.

Tavlan, Yahya Özgür, and Merve Yüksel. 2008. Metrobüs, kimine çile kimine mutluluk (in Turkish). Haber Vesaire News, October 28. Available at http:// tr.habervesaire.com/haber/1043/.

\section{About the Authors}

M. ANIL YAZICI (yazici@utrc2.org) is a research associate at Region-2 University Transportation Research Center (UTRC-II). He received B.S. and M.S. degrees in Civil Engineering from Bogazici University, Istanbul, Turkey, and a doctoral degree from the Rutgers University Department of Civil and Environmental Engineering, New Jersey. He also holds an M.S. degree in Operations Research from Rutgers University.

Herbert S. LeVinson (hslevinson@aol.com) is a transportation consultant and a University Transportation Center (UTRC) Icon Mentor. He was a senior vice president of Wilbur Smith and Associates and served on the faculty of the University of Connecticut and Yale University. He has worked on projects across North America and in many countries around the world. He is an elected member of the National Academy of Engineers, an honorary member of the Institute of Transportation Engineers (ITE), and recipient of awards from the Transportation Research Board (TRB), the American Society of Civil Engineers (ASCE), and ITE.

MUSTAFA ILICALI (mustafa.ilicali@bahcesehir.edu.tr) is the director of the Transportation Application and Research Center at Bahçeşehir University, Istanbul. He received a B.S. in Civil Engineering from Istanbul Technical University and M.S. and Ph.D. degrees in Civil Engineering from Yildiz Technical University, Istanbul.

NiLGüN CAMKESEN (nilgun.camkesen@bahcesehir.edu.tr) is the project manager, assistant professor, and coordinator of graduate studies in transportation at Transportation Application and Research Center at Bahçeşehir University, Istanbul, She received B.S., M.S., and Ph.D. degrees in Civil Engineering from Yildiz Technical University, Istanbul.

CAMILle KAMGA (ckamga@utrc2.org) is acting director of Region-2 University Transportation Research Center and an assistant professor in the City College of New York Department of Civil Engineering. He received a Ph.D. from the City College of New York in Civil Engineering. 